
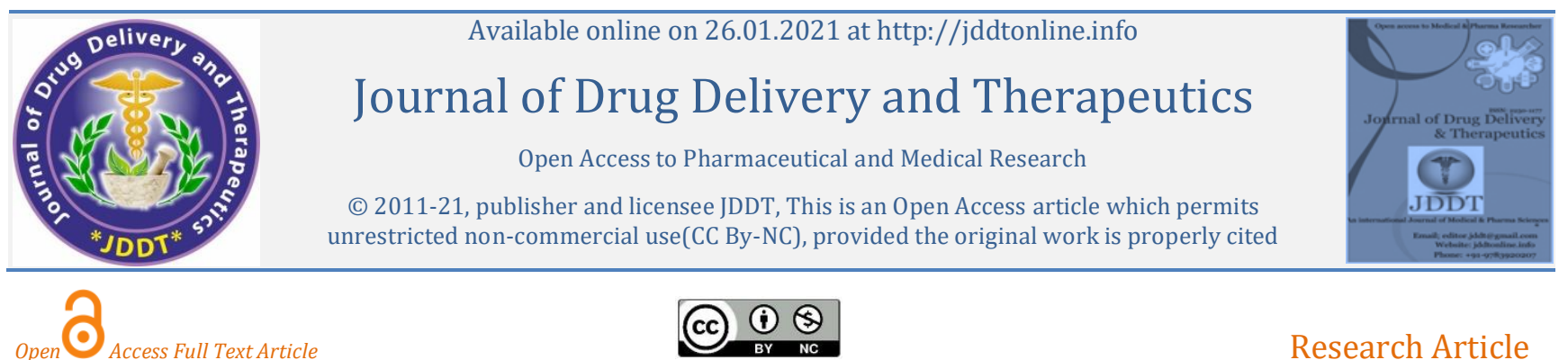

Research Article

\title{
The Effect Consumption of Red Spinach Juice on Hemoglobin on Pregnant Woman
}

\author{
Siti Saadah Mardiah ${ }^{1}$, Gina Andreyna ${ }^{2}$, Wawan Rismawan ${ }^{3 *}$ \\ 1,2 Midwifery Department of Poltekes Kemenkes RI Tasikmalaya, Indonesia 405012 \\ ${ }^{3}$ Nursing Department of STIKes BTH Tasikmalaya, Indonesia 46115
}

Article Info:

\section{Article History:}

Received 07 Dec 2020;

Review Completed 09 Jan 2020

Accepted 21 Jan 2021;

Available online 26 Jan 2021

\section{Cite this article as:}

Mardiah SS, Andreyna G, Rismawan W, The Effect

Consumption of Red Spinach Juice on Hemoglobin on

Pregnant Woman, Journal of Drug Delivery and

Therapeutics. 2021; 11(1):104-107

DOI: http://dx.doi.org/10.22270/jddt.v11i1.4706

\section{*Address for Correspondence:}

Wawan Rismawan, Nursing Department of STIKes BTH

Tasikmalaya, Indonesia 46115

\section{Abstract}

Iron needs doubled from pre-pregnancy needs. This happens because during pregnancy, blood volume increases $50 \%$, so it needs more iron to form hemoglobin One source of iron from vegetable material is red spinach (amaranthus tricolor L). One source of iron from vegetable material is red spinach (amaranthus tricolor L) to prevent anemia. The aim of this study is to determine the effect of red spinach juice on changes in hemoglobin levels in pregnant mothers of the third trimester. at Panglayungan Health Center Tasikmalaya. The research method used is preexperimental design. The population in this study were all trimester pregnant women III at Panglayungan Health Center Tasikmalaya as many as 153 people, with purposive sampling technique, with the number of samples counted 24 people. The results showed that Hemoglobin concentration in pregnant mother of trimester III before giving treatment by giving red spinach juice, have mean of $\mathrm{Hb}$ level equal to $9,7 \mathrm{~g} \%$ including light category and after given red spinach juice $\mathrm{Hb}$ content has a mean $\mathrm{Hb}$ level of $10.2 \mathrm{~g} \%$. The conclusion of this research is the influence of the consumption of red spinach juice to the change of Hemoglobin content in pregnant mother of trimester III at Panglayungan City Health Center Tasikmalaya, proved with level of significance ( $\rho v a l u e) ~ 0.000$ less than $\alpha(0,05)$.

Keywords: Red Spinach Juice, Hb Level

\section{INTRODUCTION}

The focus of health strategy is to improve awareness, capacity and willingness for everyone to live a healthy life so that an optimal degree of health can be achieved by creating an Indonesian society, nation and state that is characterized by the ability of people living in a healthy environment and behavior to achieve optimal health in Indonesia. Every part of Indonesia. A few of the United Nations Sustainable development goals is to reduce maternal mortality by three quarters during pregnancy and childbirth $1,2,3$

The incidence of pregnancy anemia around the world is quite high, ranging from $10 \%$ to $10 \%$. (20 percent ). Because food deficiency plays a very important role in the onset of anemia, it can be understood that the frequency in developed countries is even higher. The prevalence of anemia in the world is very high, particularly in developing countries, including Indonesia. According to the World Health Organization (WHO), the prevalence of anemia in pregnant women worldwide is (41.8\%) (nearly 2 billion of the world's population). $4,5,6,7,8$

According to data from the Ministry of Health, there were $305 / 100,000$ live births in 2016. Direct obstetric causes such as bleeding (28\%), preeclampsia/eclampsia (24\%), infection $(11 \%)$ are the most common causes of maternal death in Indonesia, while indirect causes include obstetric trauma (5 percent) and other causes (5 percent ). Half of maternal deaths are caused by hemorrhage, with two thirds of all postpartum hemorrhage occurring in mothers without any prior maternal risk factors. Bleeding, particularly postpartum hemorrhage, occurs suddenly and is more dangerous if it occurs in anemic women. $9,10,11,12$

Indonesia's cause much of the anemia is the lack of iron required for hemoglobin production, which is called anemia iron deficiency. Anemia in pregnant women carries high risk consequences and complications for preterm labor, prolonged labor, bleeding during and after delivery, low birth weight babies (LBW), uterine atony, uterine inertia, retention of the placenta. The indirect causes of maternal death include anemia. According to WHO, Maternal mortality (40 percent) is attributed to pregnancy anemia in developing countries. Risk factors for anemia in pregnancy include pregnancies that are too close to the previous pregnancy. The distance between pregnancies is too close to cause anemia, because the pregnancy again in a close distance will take iron reserves in the mother's body whose numbers have not returned to normal levels 13,14

The need for iron during pregnancy increases. Some literature says that iron needs are twice the pre-pregnancy requirements. This happens because during pregnancy, blood volume increases (50\%), so it needs more iron to form hemoglobin. The very rapid growth of the fetus and placenta requires a lot of iron, in a state that is not pregnant, iron needs can usually be met from a healthy and balanced diet, 
while in a pregnant state the supply of iron from food is still insufficient, so a supplement in the form of iron tablets ${ }^{15}$.

If the iron supply is minimal, then each pregnancy will deplete the body's iron supply and eventually cause anemia in the next pregnancy. In pregnancy there is relatively anemia because pregnant women experience hemodilution (dilution) with an increase in volume $(30 \%)$ to $(40 \%)$ which peaks at 32 to 34 weeks of gestation. The number of increased blood cells $(18 \%)$ to $(30 \%)$ and hemoglobin approximately (19\%). If the mother's hemoglobin before pregnancy is around $11 \mathrm{~g} \%$ then the occurrence of hemodilution will result in physiological anemia and the mother's $\mathrm{Hb}$ will be $9.5 \mathrm{gr} \%$ to $10 \mathrm{~g} \%{ }^{16,13-15}$.

Indeed, the value of iron tablets for your pregnancy can not be triggered by all pregnant women who receive iron tablets daily. The impact caused by drinking iron tablets, the body's absorption / response to iron tablets is not good, so there is no increase in $\mathrm{HB}$ levels as expected. This factor is related to anemia is the presence of bacterial, parasitic, intestinal infections such as hookworm, malaria. Low socioeconomic

\section{MATERIAL AND METHODES}

The research method used in this study is a type of preexperimental research design, with pre-test (T1) and posttest (T2) approaches. It is said to be pre-experimental design 19,20 because this design is not a serious experiment,

\section{RESULTS}

\section{Univariate Analysis}

Research findings from a univariable assessment of the impact of consumption in Panglayungan Public Health Center factors also play an important role in maternal nutrition during pregnancy 7,17

Red spinach is an iron source from herbal ingredients (amaranthus tricolor L). So far, red spinach, which is easy to cultivate, has not been widely used by the community as a source of iron for pregnant women. People, especially pregnant women, only use chemical drugs to treat and prevent anemia 18 .

The 2016 MMR crosses 16/100,000 live births and the infant mortality rate (IMR) reaching 109/100,000 live births, based on data obtained by the Tasikmalaya health office. In 2016, 10,994 pregnant women were anemic in 1,184 cases, Panglayungan Puskesmas (34.07\%), Cigeureung Puskemas $(32.62 \%)$ and in third place contributed most to the health centers in Tasikmalaya Region. is the health center of Cipedes, in particular (13.38 percent).

The author is concerned with research "the influence of the consumption of red spinach juice in Panglayungan Public Health Center in Tasikmalaya City on changes in Hb levels in pregnant women in the third quarter.".

because it ignores the covariates that can affect T2. So the experimental results which are the dependent variable are not solely influenced by the independent variable. The samples in this study were pregnant women in the third trimester who had mild anemia at the Panglayungan Health Center, with an estimated 24 people.

Tasikmalaya Area, Red Spinach Juice pretreatment and postherapeutic treatment on changes in Hb levels in the 3rd trimester of pregnant women are given in the following table:

Table 1: Frequency Distribution of Hb Levels in Third Trimester Pregnant Women before and After Consuming Red Spinach Juice

\begin{tabular}{|c|c|c|c|c|}
\hline \multirow{2}{*}{ Haemoglobin Levels } & \multicolumn{2}{|c|}{ Pre } & \multicolumn{2}{c|}{ Post } \\
\cline { 2 - 5 } & f & $\mathbf{\%}$ & f & \% \\
\hline$>11$ gr (Normal) & 0 & 0 & 15 & 62,5 \\
\hline $9-10,9$ gr (Mild Anemia) & 24 & 100 & 9 & 37,5 \\
\hline $7-8,9$ gr (Moderate Sedang) & 0 & 0 & 0 & 0 \\
\hline$<7$ gr (Severe Anemia) & 0 & 0 & 0 & 0 \\
\hline Total & $\mathbf{2 4}$ & $\mathbf{1 0 0}$ & $\mathbf{2 4}$ & $\mathbf{1 0 0}$ \\
\hline
\end{tabular}

Table 1 above shows that in Puskesmas Panglayungan, Tasikmalaya, the $\mathrm{Hb}$ levels in pregnant women before consuming red spinach juice, a total of 24 people (100\%) had mild anemia. After consuming red spinach juice, 15 people $(62.5 \%)$ were normal and 9 people $(37.5 \%)$ still had mild anemia

Table 2: Frequency Distribution of Changes in Hb Levels in Third Trimester Pregnant Women Before and After Consuming Red Spinach Juice

\begin{tabular}{|c|l|c|c|}
\hline No & Canges in HB Levels & $\mathbf{f}$ & $\mathbf{\%}$ \\
\hline 1 & Increase & 21 & 87,5 \\
\hline 2 & Permanent & 3 & 12,5 \\
\hline 3 & Decline & 0 & 0,0 \\
\hline \multicolumn{2}{|c|}{ Total } & 24 & 100 \\
\hline
\end{tabular}

Table 2 above shows that 21 respondents (87.5 percent) experienced an increase in $\mathrm{Hb}$ levels in pregnant women in the third trimester after receiving red spinach juice after treatment. In pregnant women, the average increase in $\mathrm{Hb}$ levels is $0.44 \mathrm{~g}$ per cent. 


\section{Bivariate Analysis}

The effect of red spinach juice consumption on changes in $\mathrm{Hb}$ levels in trimester III pregnant women at Panglayungan
Health Center, Tasikmalaya City can be seen in the following table.

Table 3: The Effect of Red Spinach Juice Consumption on Changes in Hb Levels in Third Trimester Pregnant Women

\begin{tabular}{|c|c|c|c|c|c|c|c|c|c|}
\hline \multirow{2}{*}{$\begin{array}{c}\text { Heboglobin } \\
\text { Changes }\end{array}$} & \multicolumn{2}{|c|}{ Pre } & \multicolumn{2}{|c|}{ Post } & \multicolumn{2}{|c|}{ Means HB } & \multirow{2}{*}{$\begin{array}{c}\text { Mann } \\
\text { Whitney U }\end{array}$} & \multirow{2}{*}{$\mathbf{Z}$} & \multirow{2}{*}{$\mathrm{p}_{\text {value }}$} \\
\hline & f & $\%$ & f & $\%$ & Pre & Post & & & \\
\hline Normal & 0 & 0 & 15 & 62,5 & \multirow{5}{*}{9,7} & \multirow{5}{*}{10,2} & \multirow{5}{*}{74,5} & \multirow{5}{*}{$-4,45$} & \multirow{5}{*}{0,000} \\
\hline Mild Anemia & 24 & 100 & 9 & 37,5 & & & & & \\
\hline Moderate & 0 & 0 & 0 & 0 & & & & & \\
\hline Severe & 0 & 0 & 0 & 0 & & & & & \\
\hline Total & 24 & 100 & 24 & 100 & & & & & \\
\hline
\end{tabular}

Table 3 above shows that changes in Hb levels that occur in pregnant women in the third trimester after being given red spinach juice, in fact there are changes in Hb levels, from 24 people who have mild anemia to 15 people $(62.5 \%)$ who are not anemia and 9 people ( $37.5 \%$ ) is still classified as mild anemia.

\section{DISCUSSION}

\section{Hb Levels of Third Trimester Pregnant Women Before Treatment}

$\mathrm{Hb}$ levels in pregnant women in the third trimester before giving treatment by giving red spinach juice, had a mean $\mathrm{Hb}$ level of 9.7 with an HB level of at least $9.0 \mathrm{gr} / \mathrm{dl}$, a maximum HB level of $10 \mathrm{gr} / \mathrm{dl}$. This shows that before consuming red spinach juice, 24 respondents (100\%) were included in the criteria for mild anemia.

The results of this study are in line with the research carried out by another researcher that the hemoglobin level of pregnant women has a mean value of 9,999 before consuming Red Spinach Juice and Honey. ${ }^{18,21}$

Hemoglobin level is a biochemical indicator to determine the nutritional status of pregnant women. Normal pregnancy there is a slight decrease in hemoglobin concentration due to hypervolemia which occurs as a physiological adaptation in pregnancy. Hemoglobin concentration $<11 \mathrm{~g} / \mathrm{dl}$ is an abnormal condition that is not associated with the hypervolemia. Inadequate hypervolemia that occurs can actually result in high hemoglobin levels in pregnant women. High hemoglobin levels in pregnant women can also result in impaired growth and normal fetal development20,18

This is in accordance with the opinion of Manuaba (2010) which states that this food consumption factor is a result of the non-fulfillment of several food sources consisting of protein, glucose, fat, vitamin B12, folic acid, vitamin $\mathrm{C}$ and basic elements consisting of $\mathrm{Fe}$, Ion $\mathrm{Cu}$ and Zinc ${ }^{21,22,23}$

\section{Hb levels of third trimester pregnant women after treatment}

Hb levels in pregnant women in the third trimester after being given treatment by giving red spinach juice mostly increased, as many as 21 people $(87.5 \%)$, and had an average $\mathrm{Hb}$ level of 10.2 with an $\mathrm{HB}$ level of at least $9.6 \mathrm{gr} / \%$, maximum HB level of $11.1 \mathrm{~g} / \%$. This shows that the average $\mathrm{Hb}$ level of pregnant women in the third trimester has an increase in $\mathrm{Hb}$ levels by $0.44 \mathrm{~g} \%$. The results of this study are in line with research conducted by Sugiarti (2014) that the hemoglobin levels of pregnant women in Gundi Village, Surabaya City in 2014 after consuming Red Spinach Juice and Honey for 3 months have a mean value of 10.44 .

The factors that affect anemia in pregnancy are divided into several factors, including factors from food consumption, the ISSN: 2250-1177
After converting it to a $\mathrm{Z}$ value, the magnitude is -4.449 with a significance level ( $\rho$ value) of 0.000 less than $\alpha(0.05)$, which means that there is an effect of consumption of red spinach juice on changes in $\mathrm{Hb}$ levels in pregnant women trimester III at Panglayungan Health Center, Tasikmalaya City.

ability of the small intestine to reabsorb the materials needed, the age of red blood cells that is limited to around 120 days, and the occurrence of chronic bleeding such as menstrual disorders, illness. which causes bleeding in women as well as intestinal parasites such as ascariasis, ankylostomiasis and taenia. However, these four factors were not controlled in this study because they required laboratory equipment and tests $5,6,18,24$.

In this study, the average $\mathrm{Hb}$ level before being given red spinach juice was $9.7 \mathrm{gr} \%$ and the $\mathrm{Hb}$ level after being given red spinach juice was $10.2 \mathrm{~g} \%$, thus almost all mothers experienced an increase in $\mathrm{Hb}$ levels, but there were 3 mothers with $\mathrm{Hb}$ levels remained after giving red spinach juice. This can be seen from the behavior of the mother's diet that is not good with a makeshift menu at home. The lack of good food menu consumption results in the inadequacy of several food sources such as protein, glucose, fat, vitamin B12, folic acid, vitamin C and basic elements consisting of Fe, $\mathrm{Cu}$ ion and zinc. According to Ahmad (2015), pregnant women are prone to anemia, because of the increased need for nutrients to produce more red blood cells, namely for themselves and the fetus they are carrying. Generally, anemia during pregnancy is mild and easy to treat if it is caught early. However, it can be dangerous for the mother and the fetus, if it is not known for a long time and is not treated. $7,8,10,13,15,17$.

\section{Effect of Red Spinach Juice Consumption on Changes in $\mathrm{Hb}$ Levels in Third Trimester Pregnant Women.}

Based on the study results, changes in Hb levels are known to occur in pregnant women in the third trimester after red spinach juice is given, in fact there is a change in Hb levels, from 24 people with mild anemia to 15 people $(62.5 \%)$ not anemia and 9 people $(37,5 \%)$ is still classified as mild anemia and changes in $\mathrm{Hb}$ levels that occur in third trimester pregnant women after being given red spinach juice as many as 21 people $(87.5 \%)$ have $\mathrm{Hb}$ levels in the increased category. The results of statistical tests show the Mann Withney-U value of 74.5 with a significance level ( $\rho v a l u e$ ) of 0.000 less than $\alpha(0.05)$, which means that there is an Effects of red spinach juice consumption on changes in hemoglobin levels in trimester III pregnant women at the Tasikmalaya City Panglayungan Health Center.

This is because before giving red spinach juice, pregnant women are prone to anemia because they need a lot of 
nutrients to produce more red blood. After the treatment was given red spinach juice, there was a change in the increase in maternal $\mathrm{Hb}$. Red spinach juice is given every day for 2 weeks to pregnant women who have mild anemia. Researchers saw pregnant women drink red spinach juice until they run out and do not cause side effects. During the distribution process, researchers have measured the distance between one respondent and another so that it does not take long. Red spinach juice without preservatives lasts a maximum of 4 hours so that the nutritional level is not reduced. So that the weakness of this study is the time needed to consume red spinach juice is quite short because red spinach juice must be consumed immediately after processing so that its nutritional substances are optimal. The need for red spinach to get iron is needed $1.750 \mathrm{~g} /$ day so that it can be absorbed by the body as much as $7.8 \mathrm{mg} /$ day. If consumed for 2 weeks, 24,500 grams of spinach are needed in the hope that it can absorb $112 \mathrm{mg}$ of iron which is close to giving Fe tablets. The consumption of spinach juice can be done 3 times a day with the amount of spinach 600 grams / 1 time consumption 2,7,8,10,13,15.

The results of this study are in line with other studies that the mean value of hemoglobin levels before consuming red spinach juice is $9.99 \mathrm{gr} / \mathrm{dl}$ and measurements after giving red spinach juice and honey have a mean hemoglobin level of 10.44. The mean difference between measurements before and after consuming red spinach juice is -0.45 which means that there is an effect of consuming red spinach juice on the increase in hemoglobin levels of pregnant women in Tawangmangu ${ }^{9,18,21,24,25}$

Red spinach juice and honey can affect the increase in hemoglobin levels of pregnant women who are anemic. Red spinach and honey contain folic acid, vitamin B1, potassium, vitamin $\mathrm{A}$, vitamin $\mathrm{C}$, calcium, and iron. The content contained in red spinach juice is useful as an anti-anemia or can increase hemoglobin levels in the blood. Red spinach juice and honey are more easily absorbed than meat or other ingredients, red spinach juice can be consumed 3 times a week for pregnant women can have an effect on increasing hemoglobin levels of pregnant women $18,21,24$

\section{REFERENCES}

1. Reinke E, Supriyatiningsih, Haier J. Maternal mortality as a Millennium Development Goal of the United Nations: A systematic assessment and analysis of available data in threshold countries using Indonesia as example.J Glob Health. 2017; 7(1). doi:10.7189/jogh.07.010406

2. Akerlof K. Nudging Toward A Healthy Natural Environment; 2013. file:///C:/Users/HP/Downloads/AkerlofKennedyNudgingtowardahealthyenvironment-2013.pdf.

3. Sukowati S, Shinta. Peran Tenaga Kesehatan Masyarakat dalam Mengubah Perilaku Masyarakat Menuju Hidup Bersih dan Sehat. 2003;xiii.

https://media.neliti.com/media/publications/159806-IDperan-tenaga-kesehatan-masyarakat-dalam.pdf.

4. Varney H. Buku Ajar Asuhan Kebidanan. Jakarta - Indonesia: EGC; 2007.

http://ucs.sulsellib.net//index.php?p=show_detail\&id=67357.

5. Ramadini I, Risma E. Faktor - faktor yang Berhubungan dengan Kejadian Anemia Pada Ibu Hamil Di Puskesmas Lubuk Buaya Padang Tahun 2015. Ners J Keperawatan. 2016;12(2):174-192.

6. Astriana W. Kejadian Anemia pada Ibu Hamil Ditinjau dari Paritas dan Usia. J Aisyah J Ilmu Kesehat. 2017; 2(2):123-130. doi:10.30604/jika.v2i2.57

7. Sukarni dan Wahyu 2013. PEMBERIAN ZAT BESI (Fe) DALAM KEHAMILAN Oleh : Is Susiloningtyas. Maj Ilm Sultan Agung. 2013.

8. Institute of Medicine. Nutrition During Pregnancy: Part I: Weight Gain Part II:Nutritional Supplements. Washington, D. C.: National Academyc Press; 1990.
http://www.nap.edu/catalog/1451.html\%0D.

9. Sumarmi S. Model Sosio Ekologi Perilaku Kesehatan Dan Pendekatan Continuum of Care Untuk Menurunkan Angka Kematian Ibu. Indones J Public Heal. 2017; 12(1):129. doi:10.20473/ijph.v12i1.2017.129-141

10. Lampung K, Tahun U, Kristianingsih A, Sagita YD, Sari M. FaktorFaktor Yang Berhubungan Dengan Kejadian Pre Eklamsi Berat Pada Ibu Bersalin Di Ruang Kebidanan Rsud Hm . Ryacudu Factors That Are Related To the Events of Heavy Exlamic Pre in Called Mother in Midwife Room of Rsud Hm . Ryacudu Kotabumi Pendahuluan . 2019; 4:20-30.

11. Utami T. ASUHAN KEBIDANAN IBU NIFAS PADA Ny. Y P 1 A0 UMUR 24 TAHUN DENGAN POST SECTIO CAESSARIA DI RSU ASSALAM GEMOLONG. Karya Tulis Ilm Stikes Kusuma Husada Surakarta. 2015:1-106.

12. Turlina Li, Ummah F, Sulistyowati. Risk Factors for Premature Rupture of the Membranes. J Kebidanan Midwiferia. 2017. doi:10.21070/midwiferia.v\%vi\%i.605

13. Hidayah W, Anasari T. Hubungan Kepatuhan Ibu Hamil Mengonsumsi Tablet Fe. J Ilm Kebidanan. 2012; 3(2):41-53.

14. Fitriany J, Saputri AI. Anemia Defisiensi Besi. AVERROUS J Kedokt dan Kesehat Malikussaleh. 2018; 4(2):1. doi:10.29103/averrous.v4i2.1033

15. Masnarivan Y, Oktriani T, Handayani R. Hubungan Kepatuhan Ibu Hamil Mengkonsumsi Tablet Fe Dan Pola Konsumsi Dengan Kejadian Anemia Di Wilayah Kerja Puskesmas Guguk Panjang Kota Bukittinggi Tahun 2015 Compliance Relations Pregnant Women Consuming Tablet Fe and Consumption With the Incidence of. J Kesehat STIKes Prima Nusant Bukittinggi, . 2015; 6(2):1-7.

http://download.garuda.ristekdikti.go.id/article.php? article=49 5966\&val=10153\&title=HUBUNGAN KEPATUHAN IBU HAMIL MENGKONSUMSI TABLET FE DAN POLA KONSUMSI DENGAN KEJADIAN ANEMIA DI WILAYAH KERJA PUSKESMAS GUGUK PANJANG KOTA BUKITTINGGI TAHUN 2015.

16. Leny. Faktor-faktor yang Berhubungan dengan Kejadian Anemia Pada Ibu Hamil. J Kebidanan J Med Sci Ilmu Kesehat Akad Kebidanan Budi Mulia Palembang. 2019; 9(2):161-167. doi:10.35325/kebidanan.v9i2.195

17. Nuraeni R, Sari P, Martini N, Astuti S, Rahmiati L. Peningkatan Kadar Hemoglobin melalui Pemeriksaan dan Pemberian Tablet Fe Terhadap Remaja yang Mengalami Anemia Melalui "Gerakan Jumat Pintar." J Pengabdi Kpd Masy (Indonesian J Community Engag. 2019; 5(2):200. doi:10.22146/jpkm.40570

18. Astuti KEW. Pengaruh Konsumsi Jus Bayam Merah terhadap Peningkatan Kadar Hb pada Ibu Hamil di Tawangmangu. 2012:72-79.

19. Arikunto S. Prosedur Penelitian : Suatu Pendekatan Praktik. (Edisi Revisi). Jakarta - Indonesia: Rineka Cipta; 2010.

20. Hidayat A. Pengertian Dan Jenis Transformasi Data. https://www.statistikian.com/2013/01/transformasidata.html. Published 2013.

21. Fatimah siti. Studi kadar klorofil dan zatbesi (Fe) pada beberapa jenis bayam terhadap jumlah eritrosit tikus putih ( Rattus norvegicus ) anemia. Jur Biol Fak Sains Dan Teknol Univ Islam Negeri Maulana Malik Ibrahim Malang Malang. 2009.

22. Almatsier, S. Prinsip Dasar Ilmu Gizi. Jakarta - Indonesia: Gramedia Pustaka Utama; 2010. https://gpu.id/bookdetail/77801/prinsip-dasar-ilmu-gizi.

23. Ruwayda. Pelaksanaan Standar Pelayanan Antenatal Oleh Bidan Di Puskesmas Kota Jambi. Media Kesehat Masy Indones. 2016; 12(2):91-97. http://journal.unhas.ac.id/index.php/mkmi/article/view/925/ 593.

24. Ruwayda, Nurmisih. HUBUNGAN KECUKUPAN KONSUMSI FE , POLA MAKAN DAN UKURAN LILA DENGAN ANEMIA IBU HAMIL DI PUSKESMAS SIMPANG KAWAT KOTA JAMBI THE RELATIONSHIP BETWEEN Fe ADEQUACY , DIETARY PATTERN AND MIDDLE UPPER ARM CIRCUMFERENCE ( MUAC) LEVEL WITH ANEMIA IN PREGNANCY AT. J Bahana Kesehat Masy. 2019; 3(2):81-87.

25. Setiawan A, Lipoeto NI, Izzah AZ. Hubungan Kadar Hemoglobin Ibu Hamil Trimester III Dengan Berat Bayi Lahir di Kota Pariaman. J Kesehat Andalas. 2013; 2(1):34. doi:10.25077/jka.v2i1.64 